\title{
Anthocyanin Extract from Flowers of Lavender dentate Beats Oxidative Stress In vitro and In vivo
}

\section{Leila Gadouche ${ }^{1}$, Abdelkader Saadi ${ }^{2}$, Khayra Zerrouki ${ }^{2}$, Noureddine Djebli ${ }^{3}$, Meryem Sendjasni ${ }^{2}$, Yasmina Djouder ${ }^{2}$, Fatima Zohra Benali Fellague ${ }^{2}$ and Kheira Benouadah ${ }^{2}$}

\author{
${ }^{1}$ University of Science and Technology Houari Boumediene (USTHB), Faculty of Biological Sciences, \\ Department of Biology and Physiology of Organisms, BP 32 El Alia, 16111 Bab Ezzouar Algiers (Algeria). \\ ${ }^{2}$ Faculty of Natural Sciences and Life, University Hassiba Benbouali Chlef, Algeria. \\ ${ }^{3}$ Pharmacognosy Api Phytotherapy Laboratory, Mostaganem University, Algeria
}

(Received: June 17, 2020; Accepted: November 21, 2020; Published (web): December 10, 2020)

\begin{abstract}
Free radicals, oxidative stress or antioxidants is more and more often used to explain different pathological disorders and their therapeutic approach. The aim of this study was to evaluate the protective effect of anthocyanin extract obtained by maceration of the flowers of Lavandula dentata in $0.1 \% \mathrm{HCl} / \mathrm{methanol}(\mathrm{v} / \mathrm{v})$ solution on oxidative stress. The antioxidant activity of anthocyanin extract in vitro was evaluated by reduction of iron (FRAP), DPPH and the $\beta$-carotene tests. The in vivo oxidative stress was induced by intraperitoneal injection of $0.5 \mathrm{ml} / \mathrm{kg}$ of $\mathrm{CCl}_{4}$ and treated orally by $500 \mathrm{mg} \mathrm{kg} / \mathrm{day}$ of the extract. Anthocyanins extract inhibited the free radical DPPH $\left(\mathrm{IC}_{50}: 1.3 \pm 0.23 \mathrm{mg} / \mathrm{ml}\right)$. Lavender extract prevented the oxidation of B carotene $(28.34 \pm 0.07 \%)$ and has an ability to reduce iron $(0.736 \pm 0.03)$. Intraperitoneal injection of $\mathrm{CCl}_{4}$ has increased biochemical parameters, which was evidence of oxidative stress in vivo. In contrast, daily oral administration of anthocyanin extract has restored the biochemical parameters. Histopathological examinations of liver stained with haematoxylin and eosin showed loss of hepatic architecture. These injuries observed have been improved by treatment with anthocyanin extract. The findings revealed that anthocyanin extract from lavender possesses a significant antioxidant activity.
\end{abstract}

Key words: Anthocyanin, Lavandula dentate, DPPH, FRAP, $\beta$-carotene, Liver, Steatosis

\section{INTRODUCTION}

Anthocyanins, a category of flavonoids in broad sense, are a natural water soluble pigments of various flowers and fruits present in food. They are formed by the condensation of an aglycone (or anthocyanidin), non-carbohydrate portion of heterosides derived from flavylium ion which is linked to one or various sugar that can be further acylated by aromatic or aliphatic organic acids. Pelargonidin, cyanidin, delphinidin, pelargonidin, petunidin, peonidin, and malvidin are the main anthocyanins widely distributed in nature ${ }^{1}$. According to Khoo et $a l^{2}$, the protective effect of anthocyanidins and anthocyanins are due to their capacity to scavenging

Correspondance to: Leila Gadouche

E-mail:gadoucheleila@gmail.com

Tel.: +213555460951

Dhaka Univ. J. Pharm. Sci. 19(2): 145-151, 2020 (December)

DOI: https://doi.org/10.3329/dujps.v19i2.50630 free-radical and by modulating cyclogenase pathway and inflammatory cytokines signaling.

Lavandula dentata is a species of Lamiaceae family native to the Mediterranean regions. It is known for its ornamental and decorative use, as well as for its economic and therapeutic importance. ${ }^{3}$ Several studies have focused on the benefits of essential oils and polyphenol-extracts from flowers and leaves ${ }^{4-8}$. Lavander possesses various biological activities. Indeed, Blažeković et al. ${ }^{9}$ have shown that the essential oil of lavender reduces bacterial and fungal contaminants which preserves the quality of food, cosmetics and pharmaceuticals products. Algeri et $a l . .^{5}$ have shown that extract of lavender displayed immunomodulatory properties in the TNBS model of rat colitis and anti-inflammatory effects in the carrageenan-induced paw edema in mice. Angustifolia lavander extract alleviated oxidative 
injury in the brain tissue and suppress epileptogenic effect produced by pentylenetetrazol in mice. ${ }^{10}$

However, no studies have been carried out on the anthocyanins of this species which make this study a unique initiative. Thus, we have evaluated the protective effects of anthocyanin extract of $L$. dentata flowers on oxidative stress produced in vivo and in vitro.

\section{MATERIAL AND METHODS}

Plant materials and phytochemical study. The species Lavandula dentata was harvested from Tenes located at Chlef (Algeria). The flowers were used in the fresh state. Before extraction of the anthocyanins, we carried out a phytochemical screening of the crude extract to identify of the classes of secondary metabolites present in flowers. Five (5) $\mathrm{g}$ of fresh flowers were infused into $100 \mathrm{ml}$ of boiling water for 15 minutes. The infused material was-filtered using Whatman fitter paper number 1 . The filtrate thus obtained was used for the detection of saponosides, tannins, flavonoids, anthocyanins etc.

Extraction of anthocyanins. The extraction of anthocyanins was carried out according to the method described by Longo and Giuseppe. ${ }^{11}$ After the detection of anthocyanins in the flowers, the extraction was made by maceration of $2.5 \mathrm{~g}$ of the flowers in $12.5 \mathrm{ml}$ of $0.1 \% \mathrm{HCl} /$ methanol (v/v) solution for 20 hours at room temperature, in dark. After filtration, the residue thus obtained was washed with $12.5 \mathrm{ml}$ of $\mathrm{HCl} /$ methanol (v/v) at $0.1 \%$, and dried using a rotary evaporator at $30^{\circ} \mathrm{C}$.

Scavenging effect on 1,1-diphenyl-2-picrylhydrazyl (DPPH). The DPPH test was-performed following the method described by Burits and Bucar. ${ }^{12}$ Here, $50 \mu \mathrm{l}$ of each of the methanolic solutions of the anthocyanin extract of lavender flowers tested at different concentrations $(0.2,0.4,1$, $2 \mathrm{mg} / \mathrm{ml}$ ) was mixed with $5 \mathrm{ml}$ of a methanolic solution of DPPH $(0.004 \%)$. After an incubation period of $30 \mathrm{~min}$ at room temperature, the absorbance was read at $517 \mathrm{~nm}$. The ascorbic acid was prepared under the same conditions for use as standard. According to Sharififar et al. ${ }^{13}$ inhibition of the
DPPH free radical as a percentage (I \%) was calculated as follows:

$$
I(\%)=\left(\mathrm{A}_{\text {Blanc }}-\mathrm{A}_{\text {Sample }} / \mathrm{A}_{\text {Blanc }}\right) \times 100
$$

Where, $A_{\text {Blanc }}$ is the absorbance of the DPPH solution without extract

$\mathrm{A}_{\text {Sample }}$ is absorbance sample of the test compound.

The $\mathrm{IC}_{50}$ index defined as the concentration of antioxidant required to decrease the initial DPPH concentration by $50 \%$ was determined. All samples were prepared in three independent experiments.

$\beta$-carotene-linoleic acid method. This test was performed according to the method described by Kartal et al. ${ }^{14}$ That consists in measuring at $490 \mathrm{~nm}$ the discoloration of $\beta$-carotene resulting from its oxidation by the decomposition products of linoleic acid. A mixture made of $0.5 \mathrm{mg}$ of $\beta$-carotene, $1 \mathrm{ml}$ of chloroform, $25 \mu \mathrm{l}$ of linoleic acid and $200 \mathrm{mg}$ of Tween 40 have been prepared. After shaking, the chloroform was removed by a rotary evaporator under vacuum. Subsequently, $100 \mathrm{ml}$ of water saturated with oxygen was added to the preceding mixture with thorough shaking. Then $2.5 \mathrm{ml}$ of the emulsion obtained are added to a series of tubes containing $350 \mu \mathrm{l}$ of each sample (extract, BHT) prepared at a concentration of $2 \mathrm{mg} / \mathrm{ml}$. After the incubation period, the absorbance of the mixtures were measured at $490 \mathrm{~nm}$. Antioxidant capacity of the sample was compared with those of BHT and the blank (only methanol).

$$
\% \text { Inhibition }=\mathrm{A}_{\mathrm{s}(\mathrm{t}=48 \mathrm{~h})} / \mathrm{A}_{\mathrm{BHT}(\mathrm{t}=\mathrm{o})} \text {. }
$$

Where $A_{S}$ represents the absorbance of test sample after incubation period $(48 \mathrm{~h}), \mathrm{A}_{\mathrm{BHT}}$ is the absorbance of control BHT at the moment of preparation $(t=0)$. All samples were prepared in three independent experiments.

Reducing power. The reducing power was determined according to the method advocated by Oyaizu $^{15}$. In fact, $1 \mathrm{ml}$ of different concentrations of each extract $(0.1,0.2,0.3,0.4,0.5 \mathrm{mg})$ diluted in distilled water was mixed with $2.5 \mathrm{ml}$ of the buffer 
phosphate (0.2 M, pH 6.6) and $2.5 \mathrm{ml}$ of $1 \%$ potassium ferricyanide $[\mathrm{K} 3 \mathrm{Fe}(\mathrm{CN}) 6]$. The mixtures were incubated at $50^{\circ} \mathrm{C}$ for 30 minutes and $2.5 \mathrm{ml}$ of trichloroacetic acid (10\%) was added. The mixture was centrifuged at $3000 \mathrm{rpm}$ for $10 \mathrm{~min}$. Then $2.5 \mathrm{ml}$ of the supernatant of each concentration was mixed with $2.5 \mathrm{ml}$ of distilled water and $0.5 \mathrm{ml}$ of $\mathrm{FeCl}_{3}$ $(0.1 \%)$. The absorbance was-measured at $700 \mathrm{~nm}$ against a blank. Ascorbic acid was used as a positive control in this experiment under the same operating conditions.

\section{Pharmacological study}

Animal models. Twenty-one female albino mice obtained from Pasteur Institute of Algiers aged 3 weeks with an average weight of $27.5 \pm 13.75 \mathrm{~g}$ were used. The animals were maintained room temperature $22 \pm 2{ }^{\circ} \mathrm{C}$ and standard $12 \mathrm{~h}$ day/night cycle. The animals were fed on a standard diet and with free access to water. Experimental protocol prepared in accordance to the Guide for the Care and Use of Laboratory Animals was approved by the scientific committee of the University. Mice were acclimated for a few days before the experiment and were distributed in cages containing 7 mice per cage.

Group I: control group that received only water. Group II: used as positive control was injected with $\mathrm{CCl}_{4} 0.5 \mathrm{ml} / \mathrm{kg}$ in olive oil. ${ }^{16}$ Group III: the test mice were treated intraperitoneally with the anthocyanin extract at the dose of $500 \mathrm{mg} / \mathrm{kg} /$ day. After the 7 th day, an intraperitoneal injection of $\mathrm{CCl}_{4}(0.5 \mathrm{ml} / \mathrm{kg})$ was administered to the group III, $30 \mathrm{~min}$ after the last in-take of anthocyanin extract. ${ }^{16}$

After one week (7 days), the mice were sacrificed, the blood was collected in heparin tubes for biochemical analysis. The liver was obtained by a longitudinal abdominal opening and was fixed in formalin $10 \%$ for histological study by hematoxylin and eosin staining.

Statistical analysis. The data was subjected to analysis of variance (ANOVA) followed by Turkey's test. $\mathrm{P}$ values less than 0.05 were considered as statistically significant.

\section{RESULTS AND DISCUSSION}

Phytochemical screening. After shaking the infused flowers, a foam obtained greater than $1.8 \mathrm{~cm}$ which showed that the tested plant contain the saponosides. The appearance of the green color in the infused lavender flowers indicated the presence of catechin tannins after addition of iron chloride. On the other hand, the purplish pink color after the cyanide reaction indicated the presence of flavonones. The presence of anthocyanins was detected by the development of purple red color after addition of ammonia to the infused flowers acidified by $\mathrm{HCl}$.

Antioxidant activity. The results obtained are expressed as percentage inhibition of the free radical (DPPH) as a function of the concentrations of the anthocyanin extract in the lavender flowers (Figure 1). The antioxidant activity exerted on the DPPH free radical by the extract was dose dependent. The anthocyanin extract effectively inhibited the DPPH free radical $(61 \pm 0,36 \%$ at $2 \mathrm{mg} / \mathrm{ml})$. The reference antioxidant "ascorbic acid" showed a very potent capacity on the free radical DPPH $(98 \pm 4.02 \%)$ at 2 $\mathrm{mg} / \mathrm{ml}$. Ascorbic acid appears to be the most active with an $\mathrm{IC}_{50}$ equal to $0.24 \pm 0.12 \mathrm{mg} / \mathrm{l}$ while the anthocyanin extract from $L$. dentata flowers have an $\mathrm{IC}_{50}$ of $1.3 \pm 0.23 \mathrm{mg} / \mathrm{ml}$ (Figure 1 ).

The ability of the anthocyanin extract to inhibit lipid peroxidation was evaluated by the $\beta$-carotene decolorization technique. Anthocyanins slightly protected the oxidation of $\beta$-carotene, with percentage inhibition of $28.34 \pm 0.07 \%$ for the $2 \mathrm{mg} / \mathrm{ml}$ concentration. However, BHT displayed most potent activity with percentage inhibition of $98.59 \pm 0.12 \%$. It protected the oxidation of $\beta$-carotene against the decomposition products of linoleic acid.

The antioxidant activity of the plant extract was investigated, by the iron reduction method, to test and determine the most active extract concentration. The results indicated an increase in absorbance which means an increase in the reducing power of the extracts tested $(0.736 \pm 0.03)$. Ascorbic acid showed strong reducing power of iron $\left(\mathrm{Fe}^{3+}\right)$ in $\left(\mathrm{Fe}^{+2}\right)$ $2.99 \pm 0.18$. while lavender has shown a weak ability. 
Biochemical study. The results obtained showed that the intraperitoneal (IP) injection of $\mathrm{CCl}_{4}$ for 7 days caused metabolic disorder, which was confirmed by an increase in blood glucose, urea, cholesterol, triglycerides ( $p>0.05$ ) and a significant increase in creatinine compared to the control group
(Table 1). The anthocyanin extract of $L$. dentata flowers caused a significant decrease in blood glucose level with intermediate values both markers of kidney function (urea, creatinine) and liver function (cholesterol, triglyceride) between the control and intoxicated mice ( $p>0.05$ ).

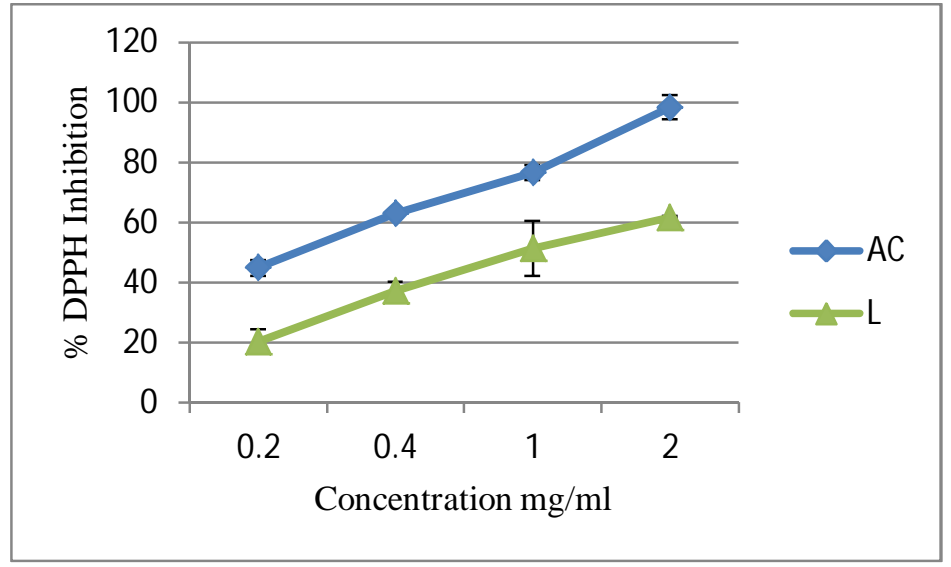

Figure 1. Antioxidant activities of anthocyanin extract of flowers of $L$.dentata as assessed by DPPH free radical scavenging $\left(\mathrm{IC}_{50}\right)$. AC: $\mathrm{IC}_{50}=24 \pm 0.12 \mathrm{mg} / \mathrm{l}, \mathrm{L}: \mathrm{IC}_{50}=1.3 \pm 0.23 \mathrm{mg} / \mathrm{ml}$.

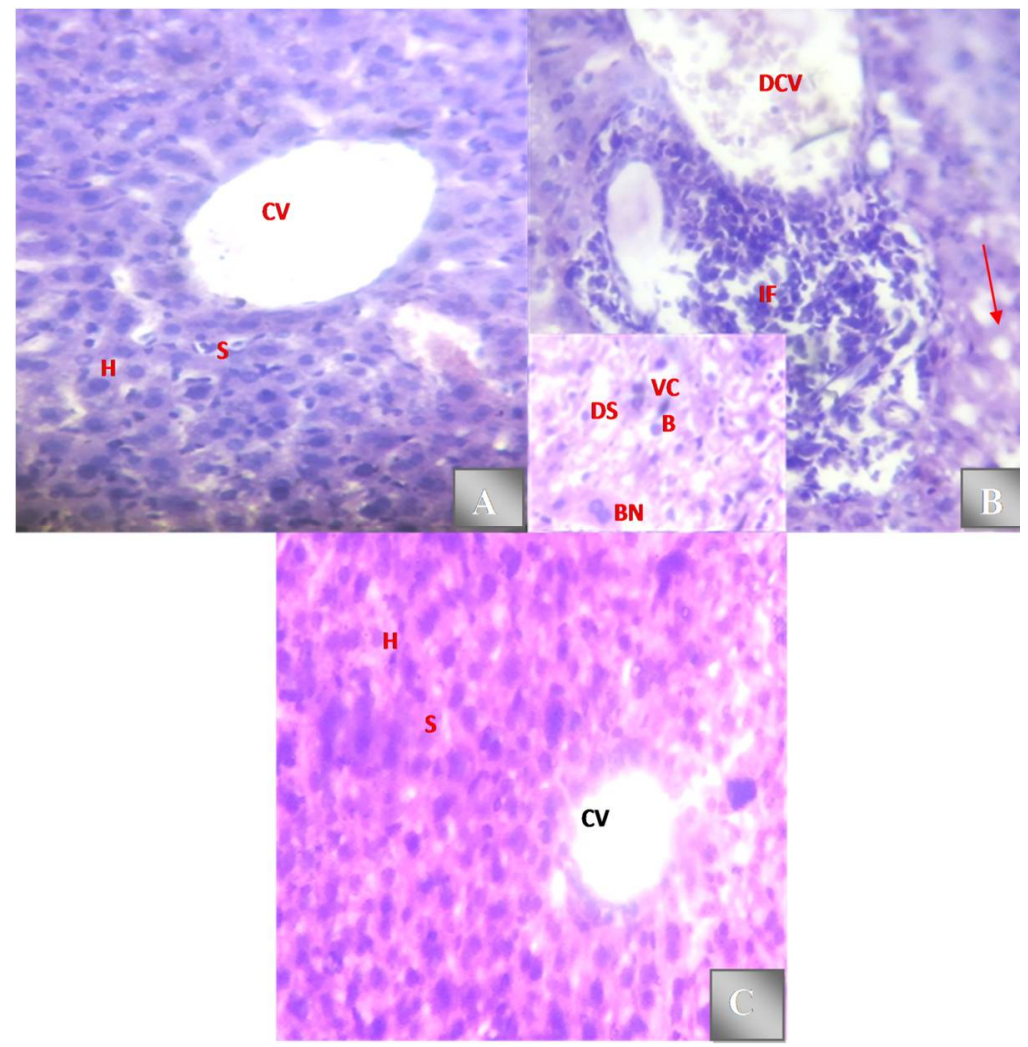

Figure 2. Photography of a section in the liver of control (A), Positive control (B), (C) treated group (H\&E staining, Gr $x$ 400). Hepatocyte (H), central vein (CV), sinusoids (S), infiltrate inflammatory (IF), dilated sinusoid (DS), vacuolated cells (V), Ballooning cell (B). red arrow: steatosis. 
Histological study. The histopathological examinations of liver stained with hematoxylin and eosin showed that exposure to $\mathrm{CCl}_{4}$ resulted in loss of hepatic architecture and necrosis such as, inflammatory infiltrate, an onset of steatosis compared to the control section. This section presents a normal hepatocyte cell and sinusoids. These observed lesions have been improved by treatment with the anthocyanin extract which has a cell architecture close to the control (Figure 2).

Anthocyanins are responsible for the color of fruits and vegetables. Many studies have shown that they have strong antioxidant properties suggesting that they have anti-inflammatory and anticarcino- genic activities. They are also able to prevent cardiovascular disease, control obesity, and alleviate diabetes. ${ }^{17}$ According to Riaz et al. ${ }^{18}$ anthocyanins have different pharmacological actions and health promoting effect such as improvement of visual performance, prevent liver toxicity, kidney diseases, colorectal cancer and enhance memory function and prevent age-related mental decline. All previous studies were devoted to lavender regarding essential oils as this medicinal plant is very aromatic. Our study with the anthocyanins extract of $L$ dentate is the first. This extract has shown an important antioxidant activity against free radicals tested by in vitro and vivo methods.

Table 1. Results of biochemical parameters after 7 days. Control group I, positive control group II, treated group III. (p $<0.05$ ).

\begin{tabular}{lcll}
\hline Biochemical parameters & Group I & Group II & Group III \\
\hline GLY $(\mathrm{g} / \mathrm{l})$ & $0.97 \pm 0.09$ & $1.03 \pm 0.22$ & $0.69 \pm 0.09 *$ \\
$\mathrm{UREE}(\mathrm{g} / \mathrm{l})$ & $0.50 \pm 0.14$ & $0.87 \pm 0.41$ & $0.82 \pm 0.08$ \\
$\mathrm{CREA}(\mathrm{mg} / \mathrm{l})$ & $3.10 \pm 0.28$ & $6.89 \pm 0.42^{*}$ & $5.40 \pm 1.55$ \\
$\mathrm{TG}(\mathrm{g} / \mathrm{l})$ & $0.88 \pm 0.20$ & $1.07 \pm 0.46$ & $0.95 \pm 0.07$ \\
$\mathrm{CHOL}(\mathrm{g} / \mathrm{l})$ & $0.61 \pm 0.49$ & $1.51 \pm 0.36$ & $0.82 \pm 0.26$ \\
\hline
\end{tabular}

In the liver, $\mathrm{CCl}_{4}$ is metabolized by cytochrome (CYP) 2E1, CYP2B1 or CYP2B2, and possibly CYP3A inducing the formation of the free radical $\mathrm{CCl}_{3}{ }^{-}$, which attacks lipids causing fatty degeneration (steatosis) and with DNA, it forms adducts initiating liver cancer. Its reaction with oxygen forms a highly reactive species: $\mathrm{CClOO}^{*}$ responsible for lipid peroxidation of various membranes of cell organelles such us mitochondrial, endoplasmic reticulum, and plasma membranes leading to alteration of calcium permeability and homeostasis which can substantially provide to subsequent cellular damage ${ }^{19}$. The IP injection of $\mathrm{CCl}_{4}$ causes a biochemical imbalance marked mainly by increase in liver and renal markers accompanied by hyperglycemia and hyperlipidemia (a good indicator of stress). This means that the administration of carbon tetrachloride for 7 days causes a malfunction of liver confirmed the presence of steatosis.
Creatinine and urea are wastes produced by increased protein metabolism. They are eliminated by the kidneys, and generally used as an indicator of kidney function. When renal insufficiency sets in, the levels of these parameters increase. ${ }^{20} \mathrm{CCl}_{4}$ also caused severe impairment of renal function with increased urea and serum creatinine compared to the control group ${ }^{21}$. The biochemical markers of renal function, creatinine, and urea were reduced in the treated group compared to the $\mathrm{CCl}_{4}$-intoxicated group. These results suggest that $L$. dentata extract reduces $\mathrm{CCl}_{4}$-induced hepatorenal intoxication.

Anthocyanin extract of flowers of lavender is considered effective in restoring the values of biochemical parameters, liver histology, demonstrating its antioxidant properties in vivo and in vitro. Several studies reported that anthocyanins decrease inflammation, oxidative stress, and liver damages (steatosis and fibrosis) $)^{22-25}$ and improve mitochondrial functions. ${ }^{25}$ 


\section{CONCLUSION}

Lavandula dentata is among the plants that is widely used in traditional medicine in Algeria as a cure for anxiety and fertility. L. dentata is one of the plants commonly consumed for its culinary and medicinal properties. Our results highlight the beneficial effects of this medicinal plant. It may be considered as an ideal therapy against oxidative stress. The anthocyanin extract has antioxidant efficacy. An adequate intake of lavender in our diet would be beneficial to our health. However, further extensive studies should be conducted to ensure its safety and efficacy.

\section{ACKNOWLEDGEMENT}

The authors thank Pr Aichouni director of Laboratory of Natural Bioresources for his assistance during this study and all the laboratory engineers of the Department of Biology, Faculty of Life and Natural Sciences Hassiba Ben Bouali Chlef University, particularly to Dr Riati Sabrina, Ms Mekraf Souhila, Ms Belazouz Asma \& Ms Saiah Chahrazed for providing us with the chemical products and equipments.

\section{REFERENCES}

1. Santos-Buelga, C. and González-Paramás, A.M. 2019. Anthocyanins. Encyclopedia of Food Chemistry, Academic Press, pp. 10-21.

2. Khoo, H.E., Azlan, A., Tang, S.T. and Lim, S.M. 2017. Anthocyanidins and anthocyanins: colored pigments as food, pharmaceutical ingredients, and the potential health benefits. Food Nutr. Res. 61, 1361779.

3. Touati, B., Chograni, H., Hassen, I., Boussaïd, M., Toumi, L. and Brahim, N.B. 2011. Chemical composition of the leaf and flower of essential oils of tunisian Lavandula dentata $L$. (Lamiaceae). Chem. Biodivers. 8, 1560-1570.

4. Hanamanthagouda, S.M., Kakkalameli, S.D., Naik, P.M., Nagella, P. and Murthy H.N. 2010. Essential oils of Lavandula bipinnata and their antimicrobial activities. Food Chem. 118, 836-839.

5. Algieri, F., Rodriguez-Nogales, A., Vezza, T., Garrido-Mesa, J., Garrido-Mesa, N.M., Utrilla, M.P. and al. 2016. Antiinflammatory activity of hydroalcoholic extracts of Lavandula dentata $\mathrm{L}$ and Lavandula stoechas L. J. Ethnopharmacol. 190, 142-158.
6. El Hamdaoui, F., Msanda, H., Boubaker, D., Leach, A. and El Mousadik. 2018. Essential oil composition, antioxidant and antibacterial activities of wild and cultivated Lavandula mairei Humbert. Biochem Syst. Ecol. 76, 1-7.

7. Dammak, I., Hamdi, Z., El Euch, S.K., Zemni, H. and Lasram, S. 2019. Evaluation of antifungal and antiochratoxigenic activities of Salvia officinalis, Lavandula dentata and Laurus nobilis essential oils and a major monoterpene constituent 1,8-cineole against Aspergillus carbonarius. Ind. Crops Prod. 128, 8593.

8. Pino-Otín, M.R., Val, J., Ballestero, D., Navarro, E., M. and Mainar, A.M. 2019. Ecotoxicity of a new biopesticide produced by Lavandula luisieri on non-target soil organisms from different trophic levels. Sci Total Environ. 671, 83-93.

9. Blažekovića, B., Yangb,W., Wang, Y., Lic, C., Kindla, M., Pepeljnjakd,S. and Vladimir-Kneževića, S. 2018. Chemical composition, antimicrobial and antioxidant activities of essential oils of Lavandula intermedia 'Budrovka' and $L$. angustifolia cultivated in Croatia . Ind Crops Prod. 123, 173182.

10. Rahmati, B., Khalili, M., Roghani, M. and Ahghari, P. 2013. Anti-epileptogenic and antioxidant effect of Lavandula officinalis aerial part extract against pentylenetetrazolinduced kindling in male mice. J. Ethnopharmacol. 148, 152157.

11. Longo, L. and Vasapollo, G. 2006. Extraction and identification of anthocyanins from Smilax aspera L. Berries. Food Chem. 94, 226-231.

12. Burits, M. and Bucar, F. 2000. Antioxidant activity of Nigella sativa essential oil. Phytother. Res. 14, 323-8.

13. Sharififar, F., Mozaffarian, V. and Moradkhani, S. 2007. Comparison of antioxidant and free radical scavenging activities of the essential oils from flowers and fruits of Otostegia persica Boiss. Pak. J. Biol. Sci. 103, 895-3899.

14. Kartal, N., Sokmen, M., Tepe, B., Daferera, D., Polissiou, M. and Sokmen, A. 2007 Investigation of the antioxidant properties of Ferula orientalis L. using a suitable extraction procedure. Food Chem. 100, 584-589.

15. Oyaizu, M. 1986. Studies on products of browning reactions: antioxidative activities of browning reaction prepared from glucosamine. Jpn J Nutr. 44, 307-15

16. Park, S.W., Lee, C.H., Kim, Y.S. and al. 2008. Protective effect of baicalin against carbon tetrachloride-induced acute hepatic injury in mice. J. Pharmacol. Sci. 106, 136-43.

17. He, J. and Giusti M.M. 2010. Anthocyanins: natural colorants with health-promoting properties. Annu. Rev. Food Sci. Technol. 1, 163-187.

18. Riaz, M., Zia-Ul-Haq, M. and Saad, B. 2016. The Role of Anthocyanins in Health as Antioxidant, in Bone Health and as Heart Protecting Agents. In: Anthocyanins and Human Health: Biomolecular and therapeutic aspects. Springer Briefs in Food, Health, and Nutrition. Springer, Cham. 
19. Weber, L.W., Boll, M. and Stampfl, A. 2003. Hepatotoxicity and mechanism of action of haloalkanes: carbon tetrachloride as a toxicological model. Crit. Rev. Toxicol. 33, 105-36.

20. Gounden V, Bhatt H, Jialal I. Renal Function Tests. In: StatPearls [Internet]. Treasure Island (FL): StatPearls Publishing.

21. Fahmy, N.M., Al-Sayed, E., Abdel-Daim, M.M., Karonen, M. and Singab, A.N. 2015. Protective effect of Terminalia muelleri against carbon tetrachloride-induced hepato and nephro-toxicity in mice and characterization of its bioactive constituents. Pharm Biol. 54, 1-11.

22. Hou, Z., Qin, P., and Ren, G. 2010. Effect of anthocyaninrich extract from black rice (Oryza sativa L. Japonica) on chronically alcohol-induced liver damage in rats. J. Agric. Food Chem. 58, 3191-3196

23. Chen, J., Sun, H., Sun, A., Lin, Q.H., Wang, Y. and Tao, X. 2012. Studies of the protective effect and antioxidant mechanism of blueberry anthocyanins in a $\mathrm{CC}_{4}$-induced liver injury model in mice. Food Agric. Immunol. 23, 352362.
24. Chen, J., Sun, H., Sun, A., Lin, Q.H., Wang, Y. and Tao, X. 2012. Studies of the protective effect and antioxidant mechanism of blueberry anthocyanins in a $\mathrm{CCl}_{4}$-induced liver injury model in mice. Food Agric. Immunol. 23, 352362.

25. Luca Valenti, L., Patrizia Riso, P., Mazzocchi, A., Porrini, M., Fargion, S., and Carlo Agostoni, C. 2013. Dietary anthocyanins as nutritional therapy for nonalcoholic fatty liver disease. Oxid. Med. Cell Longev. 145421.

26. Tang, X., Shen, T., Jiang, X., Xia, M., Sun, X., Guo, H. and Ling, W. 2015. Purified anthocyanins from bilberry and black currant attenuate hepatic mitochondrial dysfunction and steatohepatitis in mice with methionine and choline deficiency. J. Agric. Food Chem. 63, 552-561. 